\title{
TAPASZTALATOK A CSALÁDI VÁLLALKOZÁSOK ÁTÖRÖKÍTÉSÉNEK DILEMMÁI KAPCSÁN
}

A European Commission (2009) szerint a családi vállalkozásoknak számos kritériuma van; méretnagyságtól függetlenül ebbe a kategóriába tartoznak a családi tulajdonú, illetve a családok által irányított vállalkozások. A fejlett piacgazdaságok országaiban valamennyi vállalkozás 75-95\%-át adják és a világ GDP-jének kb. 65\%-át termelik meg, és Magyarországon is egyre nagyobb a jelentőségük. A magyar gazdaság egészét tekintve - a mikro- és a nagyvállalati kört is beszámítva - kb. 50 százalékos lehet a családi vállalkozások részesedése a GDP-ből. Ez a szám is jelzésértékű, hogy ezzel a vállalkozói körrel - mint fontos nemzetgazdasági tényezővel - foglalkozni kell.

A családi cégeknek számos kérdése és dilemmája van, ami nem csoda, hiszen ebben a körben a családi viszonyoknak legalább akkora a szerepük, mint a gazdaságiaknak. A sok-sok dilemma közül meghatározóan a felelős átörökítés kérdésével - tanácsadói tapasztalati vizsgálódások alapján - kíván foglalkozni a szerző - több családi cég izgalmas és leginkább tanulságos helyzeteinek elemzéseiből merítve.

Kulcsszavak: családi vállalkozások, átörökítés, generációváltás

$\mathrm{A}$ családi cégek igen jelentékeny szerepet töltenek be a piacgazdaságokban, úgy a foglalkoztatás, mint a GDP megtermelésében.

Az EU-ban a családi vállalkozások aránya 70-80\% közöttire tehető, amelyek részesedése a GDP-ből 20-70\%-os, a foglalkoztatásból pedig 40-50\%-os (Filep, 2012, p. 1.).

Az USA-ban kissé más a helyzet, ahol is a GDP-böl való részesedésük kevesebb, mint az EU-ban (50 \%) azonban foglalkoztatásban betöltött szerepük - jelentösebb 80\% (Poza - Daugherty, 2014, p. 4.).

Magyarországon a HVG (2016) szerint a vállalatok 70 százaléka családi tulajdonban van, a GDP több, mint felét ők állítják elő, valamint a foglalkoztatottak felének biztosítanak munkahelyet ${ }^{1}$.

A családi cégek között a legkülönfélébb méretnagyságok fordulnak elö. Így vannak nagyobb családi cégek is. Ezek egy részét Magyarországon a hosszú távon felelős magyar családi vállalatokat tömörítő szervezet, az FBN-H² fogja össze. Az FBN-H 2013-ban, saját tagjainak körében (jelenleg sajnos mindössze csak valamivel 50-nél több családi vállalkozás, cég a tagjuk, s így reprezentatívnak nem tekinthető az összes hazai családi cég szempontjából) felmérést készített, amelynek főbb információit a napilapok is hírül adták ${ }^{3}$. Eszerint az egyesületbe tömörült családi vállalatok összesített árbevétele a 2013-ban meghaladta a 275 milliárd forintot, miközben a foglalkoztatottságuk is figyelemre méltó a magyar gazdaság számára. Tízezres nagyságrendben alkalmaznak munkavállalókat, és átlagosan négy családtag dolgozik a saját tulajdonú cégekben, vezető pozícióban, (2013-ben húszmilliárd forintos beruházást terveztek, s ezzel további, több, mint 200 új munkahely megteremtése vált lehetővé). Az exporttevékenységük a tagcégeknél átlagosan mintegy 25 százalékos volt 2013-ig.

Mindent egybevetve még ezen - országosan nem teljes körű - adatok alapján is állítható, hogy a családi cégeknek komoly súlyuk van a gazdaságunkban. De általában a tár- sadalmi meghatározottságokban is, mivel többségükben sok olyan - a társadalmak számára fontos - értékeket képviselnek és hordoznak, mint pl. a munkavállalókért való felelősségérzet, az előállított termék szeretete és a függetlenség, hosszú távú szemléletmód, a sokoldalúság és az életre szóló elkötelezettség stb.

A fenti tényezők miatt sem ,mindegy”, hogy mi történik a családi cégekkel, s azokon belül is. Pedig permanens veszélyben vannak, s nemcsak nálunk. Ugyanis még a fejlett piacgazdaságok átlagában is - a családi vállalkozások kb. 30-35\%-a nem éli túl az ún. generációváltást. A néhány éve alakult másik érdekszövetség, a Családi Vállalkozások Országos Egyesületének egyes szakértői szerint a hazai családi cégek esetében ez az arány még kedvezőtlenebb.

A családi vállalkozások átadása kapcsán keletkező hatalmas „elhullási” veszteségnek, mint jelenségnek, számos háttér oka és nehézsége van. Az egyik legnagyobb gondot az okozza, hogy több szinten történő (anyagi, érzelmi és családdinamikai) kezelést igényel(ne) a dolog. Az átadás nehézségei sokszor széthúzást eredményeznek az ellentmondásos logikák között, hiszen egyszerre kell úgy megerősíteni a céget, hogy az fokozza a családi összetartást, kialakítani és/vagy tudatosítani cégvezetési dinasztia értékrendjét, de vigyázni kell arra is, hogy a családi cég új „feje” képes legyen a céget úgy müködtetni, hogy annak eddigi sikerei töretlenek maradjanak (Noszkay, 2011). Ezek, a veszélyt is hordozó, nehézségek gyakran a nyugdíjas korú cégtulajdonost arra késztetik, hogy tovább maradjon a cég élén, mint ahogy azt a kora és/vagy egészségi állapota megengedi.

A családi vállalkozásokkal kapcsolatos átadási, átöröklési kérdésekkel - úgy tűnik - Magyarországon is egyre inkább fogunk találkozni - két tényező kapcsán - egyre nagyobb aktualitással:

- az egyik, hogy a hazai vállalkozások (s köztük többen az eddig legsikeresebbek is) nagy része már el- 
jutott abba a helyzetbe, hogy a cégalapító „atyák” elérjék, sőt átlépjék a nyugdíjkorhatárt,

- a másik probléma, hogy Magyarországon az átörökítés kérdéskörével sem a családi cégek alapító atyái, de kutatói-oktatói szinten is csak néhányan (Noszkay, 1997, 2011, 2013, 2015, illetve újabban ld. pl. Csákné F. J., 2012 és a 2015-2016 BGE-kutatócsoportja) foglalkoznak. Sőt a tanácsadói szakmán belül is a KKV-körbe tartozó családi cégekkel kevesen", így nem csoda, ha nincs meg hozzá a megfelelö hazai szakértelem, pedig a vonatkozó szakértelemben igen jól felkészült, tanácsadói hálózattal ellátott országokban is, még az „odafigyelő”, s az utódlásra készülö, azt megtervező családi cégek esetében is esélyes a bajba jutás, sőt a totális megsemmisülés.

Az átörökítés témájával foglalkoznunk kell (a magam részéről már 1997-ben igyekeztem erre a figyelmet felhívni), hisz minden családi cég, még a legkisebbek is, amelyek nem élik túl a generációváltást, veszteség, nemcsak a családoknak, de a nemzetgazdaságoknak is.

Az is tény, hogy a családi cégekkel foglalkozni (akár kutató, akár tanácsadói szinten) egyáltalán nem könnyü, mivel a ,cégügyeket” legtöbb tulajdonos igazi „,családi ügyként” abszolút „belügyként” tartja, ami csak saját családi berkeikre tartozik. Ráadásul egy felelős átörökítési folyamat valóban több év, s a többségnek nincs elég pénze (vagy nem kíván erre áldozni), hogy ennyi időn át tanácsadó segítségét igénybe vegye. Az viszont már inkább a vonatkozó menedzsmentkultúra hiányosságainak tudható be, hogy sok tulajdonosnak semmilyen szükséges ismerete sincs az átörökítés veszélyeiröl, nem hogy a - valós kimenetet biztosító - menedzsmentmegoldások szakmai módjairól.

A fenti probléma alól némiképp kivételnek számítanak a FBN-H tagjai, amelyek - épp az egyesület segítségével - rendszeresen foglalkoznak ezzel a kérdéssel, igénybe vesznek - ha szükséges - tanácsadói és jogi szakértemet is, sőt képzést is indítottak. Ráadásul a nevezett hazai egyesület tagja a családi vállalatok európai (EFB) és nemzetközi egyesületének (FBN-I) is, így rendszeresen informálódhatnak és vehetik át 27 ország 4.000 családi cégtulajdonosának vonatkozó tapasztalatait.

Az Európai Unió - mielőtt megalkotta a saját family business meghatározását - 2009-ben felmérte a világszerte használatos családi cég meghatározásokat, s 90-féle megfogalmazást talált. Így a jelen munka szempontjából is szükségszerünek tünik, hogy tekintsük át, mit is tekintünk családi cégnek. (Erre annál is inkább szükség lehet, mivel a hazai közvélekedésben még mindig sokan a családi cégeket azonosítják a KKV-k bizonyos körével. Mi több vannak sokan - igaz jobbára nem szakemberek - akik egyesen azonosnak tartják a kettőt!)

\section{Mit nevezünk családi vállalkozásnak: meghatározás és jellemzők}

\section{A családi cég meghatározása}

Az Európai Unió 2009-ben a világon használatos 90-féle megfogalmazásból a következőket határozta meg (ld.
European Commission, 2009, p. 10.), s fogadta el mérvadónak:

Családi vállalkozásnak ${ }^{5}$ minősülnek, méretüktől függetlenül, azon gazdasági társaságok, amelyek irányításában a tulajdonos mellett legalább még egy családtag részt vesz, valamint a család tulajdoni hányada meghatározó szerepet (nyílt részvénytársaság estén minimum $25+\%$; zárt részvénytársaság esetén minimum $50+\%$ ) biztosít a családnak a tulajdonosi döntésekben.

A vezetésre és a mindennapos munkavégzésre egyaránt jellemző, hogy a család több generációja vesz benne részt. A kérdés persze az is a cégben való részvétellel összefüggésben, hogy egyáltalán ki tekinthető a családi cég „családi” részének, ami - sajnos - szintén a családi vállalkozások kutatása és vizsgálatai, s elemzései kapcsán szintén mostohán kezelt témakör. Elterjedt és használt rendszerezés szerint (a rendszerezés megalkotójának Stein (2007) tekinthető) a strukturálás az egyes családtagok részvételének fokozatait alapul véve, az alábbi:

- azok a családok, ahol minden tag, de legalább két családtag informálisan vagy formálisan részt vesz a vállalkozásban, tagja a vállalkozó családnak is,

- csak azon családtagok tartoznak a vállalkozó családba, akik informálisan vagy formálisan részt vesznek a vállalkozásban.

Az előbbiek szerint a vállalkozó családnak csak azon családtagok a tagjai, akik formálisan vesznek részt a vállalkozás müködésében. Ez a vállalkozásban való részvételre vonatkozik, s nem azonos a tulajdonlással. Hisz pl. dönthet úgy a vállalkozó család, hogy ad bizonyos tulajdonrészt (így kaphat osztalékot, részesedhet a megtermelt haszonból), a cégben nem munkálkodó családtagnak is, de ez nem azonos az elöbbiekben meghatározott körrel. Az ilyen esetek jelentős részében e családtagok jogai nem különböznek (bár elöfordulhat az is, hogy elsőbbségi jogok illetik meg öket), az esetleges egyéb, a céghez nem rokoni szálakon kötődő, tulajdoni résszel rendelkező befektetőktől.

Mindent egybevetve, a családi cégek - s éppen ezért nem véletlen a sokféle meghatározás - jelentékeny mértékben különböznek a nem családi jellegü vállalkozásoktól. Jellegzetességeik egyik oldalról az erősségeik, de másfelől a gyengeségeik is. Ez utóbbiak különösen akkor válnak kritikussá, ha a családi cég valamilyen változás előtt áll, amely változások között is kiemelkedő jelentőségű a cég tulajdonviszonyaival is erôsen összefüggő cégirányítás, vezetés átörökítése.

Napjainkra Magyarországon éppen az átörökítések kapcsán kerültek fókuszba a családi cégek! Ugyanis egyes becslések szerint hazánkban aktuálisan már több, mint 150-200 ezer családi vállalkozás esetében vált égetővé az átörökítés. Vannak azonban olyan számítások (ld. Csákné, 2012), amelyek szerint a következö öt évben a generációváltás (s csak a KKV-szektorra nézve!) hozzávetőlegesen 320.000 érintett céget jelent a 2014-2019 közötti időszakban Magyarországon. Ennek oka az, hogy a rendszerváltás után megalakuló cégek alapitó „,tulajdonosatyái”(s 
köztük többen az eddigi sikeresebbek közül) zömében napjainkra jutottak el a nyugdíjkorhatárig. ${ }^{6}$

\section{A családi cég jellemzői}

A családi cégeket több olyan markáns jellemző különbözteti meg a kizárólag üzleti alapon müködőktől, amely eltérések:

- egyfelől nehézséget okozhatnak a családi cég menedzselésében és átörökítésében,

- másfelől épp erősségeiket képezhetik, és hosszú távon fennmaradásukat szolgálhatják.

Bizonyos szerzők (pl. Huybrechts - Voordeckers - Lybaert - Vandemaele, 2011) - s magam is ezek közé tartozom a családi cégek hozzáadott értéket termelő erőforrásainak (erősségi tényezőinek) a szervezeti kultúrát, a hírnevet, az emberitőke-tényezőket és a hálózatokat tarják meghatározónak. Ezek olyan immateriális tőketényezők, stratégiai erőforrások, amelyek képesek a családi cégek versenyképességét a „legnagyobb” és a legeredményesebben működő - nem családi cégekével - azonos szintre emelni.

A legáltalánosabb családi cégjellemezőkként szokták kiemelni az alábbiakat:

a.) Egyikként szokás megjelölni általában a becsületességet, a megbízhatóságot, a törvények tiszteletét és a minőségi munkát. (Ezen a cégtulajdonságok különösen lényegesnek tekinthetők, ha arra gondolunk, hogy igen sok családi cég több éves fennállása alatt egy-egy család nevét viseli, tehát nem mindegy, hogy milyen fény vetül a vállalkozó tulajdonosra és generációira. Példaképp említhetnénk a legrégebben fennálló cégek ${ }^{7}$ közül: a japán Hoshi Ryokan vendéglátással foglalkozó és szállodát üzemeltető céget (alapítva: 718-ban), amely 46-szor élt meg sikeres generációváltást, vagy az olasz Barone Ricasoli szőlő- és olajfaültetvényeket gondozó, bort és olívaolajat értékesítő vállalkozást (alapítva: 1141-ben).

b.) Szokás kiemelni még a családfői tekintélyt is jelképező, a tulajdonos-vezető (különösképp az első generációt képviselő alapító atyára), atyáskodó (paternalista) stílusát. Bizonyos szerzők - többek között Farh és Cheng (2000), Pellegrini és Scandura (2008), Aycan (2006), Sheer (2010), Rivers (2015), Heidrich Balázs et al. (2016) - akik árnyalják ezt a stílust, a tulajdonos-vezető személyiségjegyei és attitüdje szerint. Így megkülönböztetnek jóindulatú támogató, autoriter és erkölcsi elveken álló paternalista „atyát”. Bár ezek a típusok eltérő jellegzetességekkel bírnak, öszszességében a paternalista magatartás, az, amivel az apa (legalábbis törekvései szerint) családi cége tagjait (családtagokat, alkalmazottakat is) védelmezi, óvja. A családi cégek esetében a tulajdonos részéröl gyakran tapasztalható így maximalista felelősségvállalás, a saját üzleti elképzelések kitüntetett hangsúlyú kezelése, sokszor ezzel a családtagokat távol tartva az önállóságtól és a választás és/vagy változtatás lehetőségétől (Leach, 2007; Mellerio, 2011). Ilyen körülmények között nehéz helytállni a potenciális örökösnek, tekintve, hogy szinte soha nem tapasztalhatja meg azt a felelösséget és a kockázattal járó terheket, amellyel egy-egy döntési helyzettel jár; s eközben kell bebizonyítania az alapító atyának (mielőtt az átadja neki a céget) alkalmasságát, sőt tehetségét.

c.) Lényeges tényező még a családi vállalkozások hosszú távra való „,berendezkedésére” vonatkozó (sokszor tudattalanul is megnyilvánuló) ösztönös törekvés. (Ez a fajta motiváció kvázi genetikai gyökerü, hisz, mint ahogy a családok többsége tervez gyermeket, gondoskodik az utódlásról, hasonlóan a családi cégekben is él ez a törekvés.) Azonban ez nem keverendő össze a családi cégek stratégiájával, $s$ végképp nem a stratégia tervezési tevékenységgel ${ }^{8}$. (Sokszor inkább épp az a baj, hogy ha nagy nehezen megszületik is a hosszú távú cégstratégia, a mindennapos belső családi - sokszor egyéni - törekvéseik nem, vagy alig szolgálják az általuk kitűzött stratégiát.)

d.) Végül - és eddigi tapasztalataim szerint - a legmeghatározóbb, az értékrend. Ezek két szintet képezhetnek.

Ez a két szint - ami kizárólag csak a családi cégek sajátja - egy gyakorlati ellentmondásból következik, tekintve, hogy a család és a cég - mint rendszerek - immanens értékei eltérők. Vagyis a családi cég kettős természetű, „Janus arca” van!

- Egyfelöl mint vállalkozás klasszikus jellegzetességekkel bír: árutermelő, profit- és vevőorientált, gazdálkodási egység. Fejlettségétől és életciklusától, profiljától, technikai és technológiai munkamegosztási és együttműködési viszonyaitól függő szervezeti hierarchiája és kultúrája a szervezet működésének logikájából következik.

- Miközben létezik egy másik szint, amelynek immanens értékei ettől eltérők. A családnak, mint egyfajta „fogyasztási egység”-nek, meghatározó értéke a szeretet, kapcsolatai a családi szerepekkel függnek össze, amelyek a családi hierarchiában meghatározóak stb.

1. ábra

A fenntartható családi vállalkozás elméleti modellje

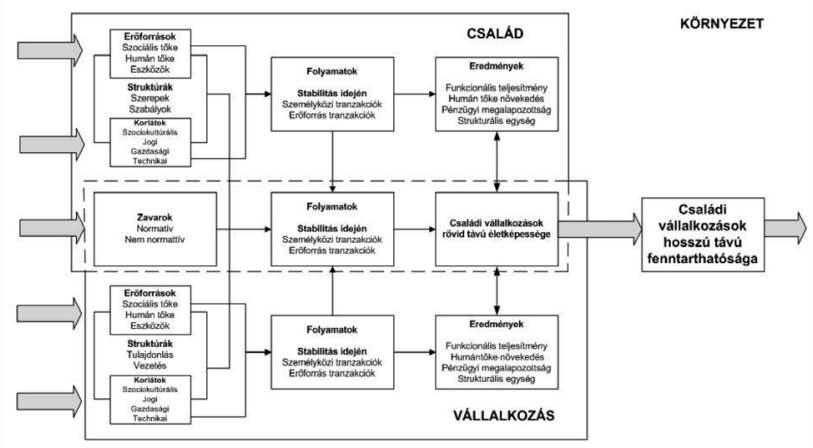

Forrás: Danes et al. (2008, p. 244.)

A két eltérő értékszint között valamiféle egyensúlyt kell teremteni, különben a két szint akár egymás ellenében, ellentétesen is, elkezd(het) müködni.

Némiképp hasonló dinamikát tételez az a fenntartható családi vállalkozási modell, amelyet Danes szerzőtársaival adott közre egyik munkájában (ld. 1. ábra). 
Az integrálást szolgálni képes szint - amely azonban csak a hosszú távon fennmaradni képesek jellemzője - a család és a családi cég következetes, kvázi szakrális értékrendje (áldozatvállalás és a felelősség a családért, a munkatársakért, hüség stb.). A családi cégek közül azok tudnak következetesen fennmaradni, amelyeknek sikerül a család és a vállalkozás értékei között harmóniát létrehozniuk. Ez úgy teremthető meg, ha az üzleti stratégia meghatározása során a család és a vállalkozás érdekei között egyfajta összhangot tudnak képezni és fenntartani, azáltal, hogy a családi és a vállalkozási stratégiákat és terveket képes a családi cég vezetése összeegyeztetni.

Általában a szóban forgó, komplex értékrendet az alapító családtag(ok) alakítja ki, és ez az értékrend - amenynyiben azt a családtagok értékrendjével is sikerül harmonizálni - képes a családi vállalkozás stabil, s a cég, mint rendszer számára megőrző, támogató, irányt szabó hagyomány ${ }^{9}$ jellegü tényezőjévé ,érlelődni” az évek folyamán.

\section{A családi cégek felelős átörökítéséről}

Elöljáróban fontos megjegyezni, hogy hazánkban az átörökítés problémája sokkal élesebben vetődik fel, mint a hagyományos piacgazdaságokban, hiszen a szocializmus fél évszázadnyi tőkés gazdálkodási rendszerének kihagyása, valamint a polgári osztály teljes felszámolása, gyakorlatilag a nulláról való építkezést tételez. Ebből a történelmi tényből következően az elkövetkezendő néhány évben fog eldőlni,

- egyáltalán újrateremtődik-e vagy sem a felelős átörökítés kultúrája ${ }^{10}$,

- a családi cégek többsége képes lesz-e olyan érett családi vállalkozássá válni, ahol több nemzedék dolgozik együtt, s képes lesz-e a vállalkozásukat generációról generációra örökítve cégdinasztiákat (céggenerációkat) felépíteni.

Van rá remény, hiszen igen sok minden szól a családi cégek generációkon át ívelő megtartására. Így:

- a családi vállalkozás által képviselt értékek (pl. a családtagok és a munkavállalókért vállalt felelősségérzet, a bizalom, a függetlenség, az elöállított termékek iránti elkötelezettség),

- a család nevének megőrzése (érzelmi és szimbolikus értelemben),

- megfelelően fenntartható családi cég esetében a biztonság (anyagi és erkölcsi értelemben egyaránt).

Kétségtelen, hogy a vállalkozás családon belül tartása, a következő generációnak való átadása, valódi és hosszú távon is reális elönyöket biztosít, amit egyetlen családnak, de a nemzetgazdaságnak sem szabad veszni hagyni. Azonban jellegzetes az az alapvető kérdés: vajon van-e akkora „felismerő képesség” (s nemcsak az alapító atyákban, de a családtagokban is), hogy mindezt átlássák, s megfelelő időben, s kellő energiát fordítva rá, a szükséges módszertani alapokra eljussanak ${ }^{11}$ és foglalkozzanak az átörökítés folyamatával.
Persze ennek a dilemmának további sok más, további részkérdése van. Így:

- van-e a családi cégen belül olyan, számításba jöhető utód, aki esélyes a cég átvételére,

- milyen az életkori inkompatibilitás (túl nagy a korkülönbség az átadásra készülő atya és a gyermekei között),

- a gyermek más pályára készül és/vagy saját útját akarja járni (esetleg inkább alapítana egy saját céget), - az előd nem akar, nem tud visszavonulni, nem tervezi az utódlást,

- a gyermekek nem becsülik a vállalkozást és/vagy nem képesek kockázatokat felvállalni,

- a vállalkozás nem igazán képes a fennmaradásra (pl. nem igazán piacképes a portfóliója, állandó tőkehiánnyal küszködik, nincs semmilyen stratégiája, a „,pillanatnak él” stb.).

Nem kívánok a fenti dilemmák közül mindegyik - a szakirodalom által is - sokat és sokak által taglalt részleteire kitérni, mivel ez terjedelmi korlátok miatt úgy sem lehetséges. Megemlíteném azonban, hogy megfelelő átöröklési processzus híján minden élet- vagy versenyképes cég esetében - örökös utódlás híján - még a tulajdonos atya nyugdíjba vonulása előtt (de akár elhalálozása esetén is), minden jobb megoldásnak tekinthető, mint megvárni a felszámolást. Hiszen számos megoldás inkább célszerü lehet úgy a család, mint a nemzetgazdaság érdekeinek szempontjából.

Felszámolás/végelszámolás helyett, például számításba jöhet:

- a vállalkozás teljes megosztása testvérek között ha az üzletileg is reális (amennyiben az örökhagyó már aktív korában felismerte, hogy eleve esélytelen, hogy a következö generáció együttmüködjön, s a céget sem szeretné eladni),

- a vállalkozás eladása, ha nincsenek örökösök vagy a potenciális átvevők más hivatást választottak,

- tanácsadó segítségével interim menedzsert megbízni, amennyiben az utód alkalmas, csak még kora és/ vagy gyakorlata végett nem veheti át plusz kockázatok nélkül a céget,

- hivatásos menedzsment kinevezése (megfelelő kontroll mellett, de a tulajdont meghagyva), ha nincs megfelelö utód a családon belül.

Nyilván egészen más a helyzet, ha van megfelelő potenciális utód(ok), s az átörökítőben is meg van az a hajlandóság, hogy az utód(ok) megfelelő felkészítése és az átadás kellő gondossággal végigvitt processzusa mentén, még „időben” átadja a céget.

Mindezek dacára így is, ilyen tudatos elhatározás és az utód(ok) megfelelő családi - és üzleti szocializálása esetén is, a családi vállalkozások életében az utódlás a konfliktusokkal leginkább terhelt időszak és folyamat. A családi vállalkozásokban felmerülő feszültségek, konfliktusok megoldását nehezíti, hogy a családi viszonyok azo- 
kat minduntalan átszövik, keresztezik. A konfliktusok közül kiemelkednek és a legsúlyosabban esnek latba az apa-fiú(k) konfliktusai, illetve a testvérek rivalizálása, a lánytestvérek háttérbe szorítása. Ez utóbbiak, még megfelelő, az átadást indító „,megegyezés” (átvevői szerepfelosztások, cégértékek és stratégiai irányok stb.) esetén is képesek akár, nemcsak megzavarni a családi vállalkozás operatív müködését, de elmérgesedő, nem kezelt konfliktusok esetén, az átadási folyamatot is ellehetetleníteni.

\section{Tanácsadói és oktatói tapasztalatok - hazai családi cégek köréből}

\section{Előzmények}

Néhány éve mind gyakrabban találkozom - ahogy a Változás- és Válságmenedzserek Országos Egyesületének (VOE) más szakértői, tanácsadói is - a hozzánk forduló kliensek között olyan családi cégekkel, amelyek nem vagy nem időben, illetve nem a megfelelő módon foglalkoztak az átörökítés kérdésével.

A magam részéről már igen hosszú ideje napirenden tartom tanácsadói, kutatási és oktatói témáim között a családi cégek problémáit (e munka során is a vonatkozó saját, illetve mások tanácsadói eseteiből is feldolgozásokat végeztem, tapasztalatokat összevetettem, módszertani szempontból integráltam, az oktatásban is felhasználtam).

Tekintve azonban arra, hogy az utóbbi években ezek az érdekszövetségünk tagjai által jelzett tapasztalatok súlyosbodtak, arra késztetettek, hogy ne csak - a gyakran már reménytelennek bizonyuló - esetek feldolgozásával jussak közelebb a hazai átörökítés kérdéseihez, hanem a látszólag kedvezőbb helyzetet mutató családi cégek átörökítés közeli helyzeteinek megismerése révén is.

Így néhány áldozatkész kolléga és tanítvány segítségével belefogtunk - egy olyan vizsgálatba, amely a KKV-szektorhoz tartozó családi cégek köréből ${ }^{12}$ merített.

A vizsgálatnak kettős célja volt:

- egyfelöl képet kapni arról, hogy vajon azok a családi cégek, amelyek kedvezőbb adottságokkal (növekedés és fejlődés, az erőforrások, piaci helyzetük stb.) bírnak, tehát az átlagosnál, cégvezetés szempontjából is, vélhetően felkészültebbek, foglalkoznak-e, és ha igen, milyen dimenziók mentén a náluk is potenciálisan veszélyt jelentő átörökítés kérdéseivel,

- másfelől ha igen, találhatók-e olyan - módszertani szempontból felhasználható - momentumok, amelyek a hazai családi cégek ${ }^{13}$ átörökítési folyamatának, a cég, de tanácsadói szempontból is sikeres véghezvitele szempontjából figyelemreméltóak $\mathrm{s}$ hasznosíthatóak?

Mint erről már esett szó, a saját és a VOE eddigi tanácsadói és válságkezelési tapasztalataink igen lesújtóak voltak a KKV-körhöz tartozó családi cégek esetében. (Persze ez részben a szakma jellegzetességeinek is betudható, hisz a VOE a bajba és/vagy a növekedés és fejlődés útját járó $\mathrm{KKV}$-cégek változáskezelésére spe- cializálódott.) Azonban más cégekkel való összevetésben jóval nagyobb arányban találkoztak szakembereink olyan, KKV-körbe tartozó családi céggel, amelyet - az első felmérés után - etikai okokból nem vállalhattak el, mivel az nyilvánvalóan menthetetlen állapotban volt, s ezért egyértelmüen egy másik szakma, a felszámolás, körébe kellett utalni. Hozzá kell tennem, hogy ez utóbbiak számossága $\mathrm{kb}$. a duplája volt annak, amelyeket a VOE szakemberei egyáltalán felvállalhattak, s még ez utóbbiak közül is csak mindössze néhány családi cégröl mondható el, hogy van/volt esélye az átörökítés sikerére, ugyanis a többségben voltak azok,

- amelyeken épp csak olyan szintig lehetett segíteni, hogy a cég eladható állapotba kerüljön,

- de nem kis számmal voltak olyanok is, akik - miután szembesültek azzal, hogy az átadási processzus milyen aktivitásokat követelne tölük - megváltak a tanácsadó szakembertől.

Vagyis - megítélésem szerint és az eddigiek alapján, tapasztalati alapon leszürhető - a KKV-körbe tartozó családi cégek átörökítésének kérdésében, hazánkban igen komoly gondok tapasztalhatók.

Az elöbbi indítékok alapján került sor a napi praxison túlmutató felmérésre, amely nem tekinthető reprezentatívnak (inkább pilot-jellegü), azonban konklúziói mindenképp tanúságosnak ítélhetők.

\section{A vizsgálat megfontolásai, hipotetikus feltételezései}

A vizsgálat módszereként félig strukturált interjúra esett a választás. Ez a módszer ugyanis - bár van egy előre megfogalmazott kérdéssora, amelyet a kérdezőnek érinteni kell - elég rugalmas ahhoz, hogy a kérdező ne akadjon el, ha egy adott témába az alany nem, vagy csak nagyon szükszavúan akar belemenni. Esetleg, ha adódik olyasmi amit akár a kérdező, akár az alany menetközben fontosnak ítélt (pl. elöre nem meghatározott irány, téma), legyen mód kitérni rá.

Viszonylag számos (hozzávetőleg 48 db) családi cég elérhetőségeit sikerült begyüjteni, de - az előzményekben vázolt célok alapján - ebböl csak olyan cégekre esett a választás, amelyekre a következő kritériumok voltak a jellemzők:

- nem spekulációkra épült, profilja - alapítása óta némi folytonosságot képez,

- a cég legalább 18-25 éves múlttal rendelkezik, a tulajdonos alapító és/vagy első generációs,

- a cég a fennállása óta mutatott növekedést, illetve némi fejlődést is.

Így végül a vizsgálatba 35 céget $^{14}$ sikerült bevonni. A vizsgálatot megelőző hipotéziseim az alábbiak:

- a cég fennállásának évei alatt napjainkra már kialakult a cég (a cég tulajdonos) által vallott értékrendje, 
- van a cégnek valamilyen szinten megfogalmazott stratégiája,

- a vállalkozás müködtetése viszonylag stabil (formalizált) rendben müködik,

- viszonylagosan kedvezőbben állnak az átörökítési problémához, és léteznek megfelelő szempontok alapján alkalmasnak ítélt örököse(i), jelöltje(i) a tulajdonosnak (s az örökös kiszemelése valamilyen - a családi érzelmeken túlmutató - komolyabb szempontok alapján történik),

- az átörökítőnek vannak átadási tervei, hogy valami olyan fajta fokozatok mentén adja majd át a céget, amely időben is segíti az örökös jelöltet a felkészülésre, s nem fog hirtelen rázuhanni az ,egész”.

Az előbbi feltételezésekben megfogalmazottak, interjúkérdésekké formálva képezték az interjúk strukturális vázát (az alkérdéseket terjedelmi okok miatt nem közöljük), az alábbiak szerint:

a.) gondolkodtak-e már azon, hogy kidolgozzanak követendő értékrendet cégük számára, illetve ha már van ilyen, melyek azok,

b.) van-e érvényes szervezeti- és müködési szabályzatuk, s ha igen, vannak-e mellékletei és melyek ezek,

c.) ha ön (a tulajdonos) nyugdíjba megy majd, szeretné-e, hogy a cége a család tulajdonában maradjon, vagy a céggel más tervei vannak (ha más tervei vannak miért és mi),

d.) ha a családi tulajdonban gondolkodik, akkor ki lenne az örököse (s miért épp ő vagy ők),

e.) hogyan és miképp készül a leendö örökös a cég vezetésére?

\section{Vizsgálati eredmények}

Az interjúkból leszürhető eredményeket, vonatkozó tapasztalatokat a hipotézisek sorrendjében foglaltam csokorba. Bár ezek az eredmények - a remélttel ellentétben - kedvezőtlenebb képet mutattak, mégis a vizsgálat szereplöinek sokkal jobbnak "jósolhatók" az átörökítési esélyei. Kétségtelen ugyanakkor, hogy igen sok, kezelésre szoruló probléma is tornyosul elöttük.

\section{Mennyire jellemzö a családi cégekre a megfogalmazott és betartásra esélyes értékrend?}

Nagyon érdekes a megfigyelés és a tapasztalat, hogy az ún. nagyon élőmunka-intenzív ágazatokhoz tartozó, tradicionális, illetve az ősi hagyományokkal is bíró technológiák (ebben meghatározó a szőlőtermelés, a borkultúra, a gyümölcstermesztés, illetve a pálinkakészítés, a tejágazat egyes területei, a kenyér és száraztészta stb.), vagy az ipari jellegü, de szintén hagyományokra épülő technológiájú cégek (pl. pipakészítés, minőségi szabóságok, a népi hagyományokra is épülők: pl. szőttesek, szőnyegek, hímzések stb.) a többségükben rendelkeznek értékrenddel, söt a család által is vallott és elfogadott, összehangolt értékrenddel.

Ezek közül is stabilak értékeik megfogalmazásában és örzésében azok, ahol nemcsak a tulajdonos jelenléte, elkötelezettsége és motivációja alapvető, de az adott cég és technológia tradicionális kvalifikációit biztosító specialitásai is (pl. bizonyos receptúrák, az íz és ízlés - igények stb., illetve a nagyformátumú előd örökségére, speciális tudására, szakértelmére épül). S hazánkban még mindez kiegészül azzal is, hogy azon családi cégekben - még ha ez a rendszerváltás után nem is volt olyan tudatosan kezelt, mint napjainkban -, ahol valahogy megőrizhető volt a technológia kultúrája (pl. a kis háztájiban, vagy az egyszemélyes ,,maszek” cégek üzemeltetésével stb.) ott viszonylag gyorsabban és jobban tetten érhető az ,értékregenerálódás", mint ahol a családban semmilyen előzménynyel sem bírt az adott termelés.

A minden hagyományt nélkülöző és abszolút „történelmi múlt" nélküli családi cégek esetében (pl. általában a gépipari és a többi cég) is tapasztalhatók voltak eltérések: pl. a gépipari technológiák (vagy egyáltalán olyan technológiákat alkalmazó cégek) esetében, ahol a technológiai eljárásoknak nagyon kemény elöírásoknak kell megfelelniük, azoknál kb. a 2/3 már elindult azon az úton, hogy foglalkozzon az értékrend kialakításával is.

\section{A vállalati stratégia}

A vállalati stratégia kérdésében átlagosan sokkal kedvezőtlenebb a helyzet. Még a stabil értékrenddel bíró családi cégek esetében is $\mathrm{kb}$. a felének nincs igazán értékelhető stratégiája. A többségük fejében valamiféle „ködbe vesző", s csak nagyvonalakban körvonalazott stratégia (a tulajdonosok nevezik annak) létezik. Azonban olyan igényesen kialakított, majdani teljesüléseit is számon tartható/"mérhető" stratégia kidolgozásába nem fektetnek kellő energiát. E tekintetben sokkal jobban állnak a tudásigényes szolgáltatásokat produkáló cégek, náluk azonban az a baj, hogy szinte alig van köztük olyan, ahol szóba jöhető örökössel bírnak/vagy számolnak. Többségüknél a számításba jöhető örökösök inkább saját cégben gondolkodnak, vagy épp a potenciális átadó gondolja azt, hogy nincs ahhoz kellő tehetsége a potenciális jelöltnek, hogy hosszú távon fennmaradni, növekedni tudjanak, ezért inkább a későbbi eladást tervezik. Azt azonban hozzá kell tennem, hogy e cégek köréből kerültek ki többségükben kb. 18 évnyi müködésü cégek, s a tulajdonos atyáknak is van még a nyugdíj kor eléréséig kb. 8 -10 évnyi idejük.

\section{A családi cég müködtetésének szabályozottsága}

Ez utóbbinak a léte azért alapvető, mert még ha örökösödési processzus nélkül is ,szakad rá” és kell átvennie valamelyik utódnak hirtelen (betegség vagy haláleset okán) az örökséget, jóval könnyebb dolga adódhat, mint a családfó által „kézi vezérelt” (szinte mindent csak a „,kockásfüzetből” nyomon követhető és rekonstruálható) vállalkozásnál. Sajnos ez a dolog a vizsgált cégek többségénél igen csak „hadilábon” áll. Viszonylagos s jó értelemben vett kivételt képeznek a gépipari, illetve „kemény" technológiai eljárásokra alapuló cégek, amelyek üzemeltetése - egy méretnagyságon túl - másképp gyakorlatilag elképzelhetetlen. A megfelelő és áttekinthető szabályozottság egyébként a vizsgált cégek esetében $\mathrm{kb}$. a $65 \%$-ra volt jellemző. 
Szabályozottságban legkedvezőbb helyzetünek a gépipari beszállító cégek bizonyultak, ami nem meglepö, hiszen működésüket a megrendelőjükhöz szükségszerü igazítaniuk.

\section{Az átörökösítési terv és az örökös kiválasztása}

Sajnos épp ebben a kérdésben a legrosszabbak a tapasztalatok. A vizsgált cégek 2/3-ánál semmilyen átörökösítési elképzelés, terv sincs, nem hogy átörökítési folyamat. Azon családi cégek, amelyek technológiái hagyományokkal rendelkeznek, ebben a tekintetben a hazai átlagnál jobb helyzetben vannak. Ugyanis sokuknál egyfelöl a családi értékek reneszánszukat élik, másfelől sokkal kedvezőbb az ún. természetes, szerves fejlődésű családi szocializáció, vagyis az a mozzanat, hogy az örökös(ök) szinte gyermekkoruk óta:

- megtanulják megbecsülni - hisz jobban „,beleszövődik" a mindennapjaikba - a hagyományos technológiák kultúrájából fakadó tevékenységeket,

- ezen cégek többségénél - már kora gyermekkortól - bevonják az utódokat a munkafolyamatokba, konkrétabban is megismerik a ténylegesen a cégnél zajló technológiai munkafolyamatokat. (Bár ez néha kétélü, mivel vagy megszeretik azt, vagy egy életre elmegy tőle a kedvük. Egy biztosan mondható, hogy valamilyen kényszerhelyzetben - még ha átmenetileg is - de, jóval biztosabb kézzel képesek irányítani azt, mint olyan társaik, akiket - részben kíméletből, vagy a cégtevékenységnek valamilyen zárt, esetleg balesetveszélyes, technológiai rendszerének, részeiből, vagy egészéből rendre kívülre rekesztenek.)

Sokkal mostohábban müködik az utód felkészítése kapcsán - szinte valamennyi cég estében - az ún. üzleti szocializáció, vagyis az a nagyon fontos felkészítési folyamat, amely magába az üzleti - gazdálkodási - menedzsmenttevékenységbe vonná be az utódot. Ez ugyanis az a kényes terület, amit senkivel, sokszor még házastársával sem oszt meg a családi cég feje (különösképp pl. az üzleti adatok sarokszámait illetően). Ez nagyon nagy baj, nemcsak a bizalmatlanság légköre miatt, hanem azért is, mivel az örökös így nem szerezhet rutint a menedzselés kérdéseiben. (Sokszor ott áll egy hirtelen tragédia után tanácstalanul, mivel nem csak, hogy nem ismeri a cég partnereit, a cég bankjában sem járt még érdemben el egyetlen komolyabb ügyben sem, de még a vállalkozás termékparamétereivel, aktuális megrendeléseivel sincs tisztába, így egyik percröl a másikra egyetlen egy tárgyalást sem tud érdemben lefolytatni.)

Pedig az üzleti szocializáció nagyon hasznos lehet egyfelöl a jelölt üzleti alkalmasságával is jobban van esélye az átörökítőnek és utódnak is szembesülnie, másfelöl a jelölt is megszerezheti azt a fontos rutint, ami a vállalkozás mindennapjai kapcsán alapvető követelmény. Nem beszélve arról a bizalomról, sőt önbizalomról, ami nélkül semmi szín alatt nem lehet jól és tartósan együttmüködni cégfönek és utódnak.
Az utódkijelölés kérdésében szintén azon - jobbára hagyományokkal rendelkező, ősi termelési kulturális gyökerü - cégek állnak jobban, ahol és akiknél a jelölt(ek) már gyermekkoruk óta részt vesznek a munkafolyamatokban. Ez esetben ugyanis a jelölt valódi viszonyulása és motivációja a családi cég tevékenysége iránt az átörökítő számára nyilvánvalóbbá válik. (Az persze egy teljesen más kérdés, hogy előfordul ilyen cégfök esetében is, hogy az érzelmek ,átírják” a józan megfontolásokat, de sokkal ritkábban.)

\section{ÖSSZEFOGLALÁS}

Mindent egybevetve, bár a vizsgáltak köre nem reprezentatív, sikerült - nemcsak régebb óta müködő, de fejlődő, az évek alatt növekedést is produkáló - olyan családi cégeket bevonni, amelyek lehet, hogy induláskor valamilyen gazdasági kényszer következtében kezdtek el vállalkozni, de napjainkra már jelentőséggel bíró szereplőivé váltak gazdaságunknak. Ha megnézzük gazdasági eredményeiket a többségük árbevétele már több milliárd forint, likviditásuk mérhetően stabil, s évről évre elfogadható nyereséget is realizálnak. Tehát minden ok meg van azt állítani, hogy akár egyetlen ilyen cég elvesztése, valóban nemcsak a család számára, de a nemzetgazdaság számára is, sajnálatos veszteség. Azonban, ha mindez egyszerre több vállalkozással is - hisz az átörökítési anomáliáival összefüggő kockázatok valódi fenyegetettségek - megtörténne a gazdaságban, az már komoly kiesést is jelenthetne. Pedig sok cég megmenthetö volna az átörökítési folyamat felelösségteljes felvállalásával.

Számomra úgy tünik, hogy az átörökösítési hiányosságok többsége mögött nem annyira a családi cég fejének, illetve a család tagjainak a nemtörődömsége áll, inkább a vonatkozó nem tudás, az ún. átörökítési kultúra teljes hiánya és a megfelelően elsajátítható modell és módszer az ok.

Igaz, s még az elöbbiekbe is nyilván belejátszik, hogy sok tulajdonos családfö „halhatatlannak” hiszi magát, a családtagok meg ilyen felfogással szemben nem szívesen vállalják fel a valósággal való szembesítést, s az ezzel járó, esetleges és súlyos konfliktusokat, kellemetlen családi viszályokat.

Így jogos a feltételezés: hogy nagyon sokat segítene a hazai helyzeten, ha a felelös átörökítés kérdéseiben az oktatásban, képzésben, az elemi szintű tudnivalókban és a tanácsadásban kiemelten a kamarák és a felsőoktatás is megfelelő szerepeket vállalnának. Hasonlóan más, fejlettebb piacgazdaságokhoz, ahol is komolyan és időben foglalkoznak azzal, hogy a felelös átörökítés valamennyi szereplőjét időben felkészítsék.

Epilógus: A sok éves kutatói, tanácsadói és oktatómunka, valamint a jelen munkából származó, „nyomatékosító” eredmények nem voltak „hiábavalók”, integrálásukkal ugyanis közben megszületett a FABU - a felelős átörökítés módszerének kísérleti szakaszba jutott verziója -, amelynek többoldalú „tesztelésével” referenciák, azok révén pedig a módszertani oldal „kikristályosodása" is remélhetö. 


\section{Jegyzet}

1 A családi cégeknek a gazdaságban betöltött szerepe és súlya dacára sajnos a hazai családi cégekről aránytalanul kevesebbet tudunk, mivel önállóan rájuk nézve nincsen KSH adatgyüjtés.

2 Pontos megnevezése: Felelős Családi Vállalatokért Magyarországon Közhasznú Egyesületet

3 http://www.napi.hu/magyar_vallalatok/erosodnek_a_csaladi_vallalkozasok.552232.html

4 Akad néhány érdekes tanácsadási kezdemény ld. pl. http://csaladivallalkozasokrol.hu/, vagy a Változás- és Válságmenedzserek Országos Egyesülete és azon belül több szakértő is, illetve a néhány éve alakult egyesület, Családi Vállalkozások Országos Egyesülete névvel - ld. csvoe.hu - is, amely szintén a családi cégeket egyesíteni és érdekeiket képviselni hivatott.

5 Érdekes, hogy az FBN-H, bár szintén elfogadja és használja a EU-s meghatározást, a hazai családi cégeket tovább bontja - a kelet-közép-európai gazdasági fejlődés által indokolva - a családi cégek elhatárolását, az alábbiak szerint:

„Magyarország - Top 100 - Családi Vállalatok: 50+ föt foglalkoztató évi legalább egymilliárd forint hozzáadott érték típusú (árbevételELÁBÉ) forgalmat legalább generáló vállalatok, amelyek tulajdonosi köre meghatározóan egy családból kerül ki és a cégvezetésben a tulajdonoson kívül legalább egy családtag részt vesz (ld. FBN-H infoHUN.pdf letöltve: http://www.fbn-h.hu/ 2014.06.14.).

Magyarország - Hot 500 - Családi Vállalkozások: 15-49 föt foglalkoztató évi 300-999 millió forint hozzáadott érték típusú (árbevétel-ELÁBÉ) forgalmat generáló vállalkozások, amelyek tulajdonosi köre meghatározóan egy családból kerül ki és a cégvezetésben a tulajdonoson kívül legalább egy családtag részt vesz,, (FBN-H http://www.fbn-h.hu/).

6 A rendszerváltás nagy cégalapító „,boom”-jának idején, az egyik szaklap megalkotta a tipikus magyar vállalkozó ,profilját”, ami szerint az akkori évek tipikus magyar vállalkozója: férfi, mérnök s korát tekintve 40-45 közötti.

7 Hasonló cégeket még ld. A világ legrégibb családi vállalkozásai www.griequity.com/resources/industryandissues/familybusiness/oldestinworld.html

http://www.ugyvezeto.hu/cikk/60158/a-vilag-15-legregebbi-csaladi-vallalkozasa-a-tradicio-orzese-es-fejlodni-tudas-a-titok?area=166

8 Ebben a kérdésben többen is igyekeznek rendet vágni (többek közt ld. Carlock - Ward, 2006).

9 Hamvas Béla szerint: ,,A hagyomány nem rendszer, hanem rend. A rend arról ismerhető fel, hogy önmagát állandóan javítja. A rendszer organizáció, a rend organizmus. A rendszer, ha valahol nem jó - márpedig mindig kiderül, hogy valahol nem jó - összeomlik. Ha a rend valahol nem jó, önmagát kijavítja. A hagyomány nem rendszer, hanem rend, minden számunkra ismert alakjában, a kínaiaknál, a hinduknál, a hébereknél, a görögöknél. A rend nem zárt és statikus épület, hanem nyílt irány és út" (Hamvas, 2008, p. 182.).

10 A probléma az, hogy a felelős átörökítés kultúrája nemcsak „cégmenedzsment”, de még csak nem is kizárólag „,vállalkozói kultúra” kérdése. Annál sokkal mélyebb társadalmi - pl. a család társadalmilag elfogadott és értékelt helye és szerepe, a családon belüli szocializáció a generációk közötti kölcsönös tisztelet és megértés, illetve a testvérek egymáshoz való viszonya stb. - kérdései is.

11 A fejlett piacgazdaságokban a kamarák a legkülönfélébb módon (tanfolyamok, tanácsadói hálózatok, kiadványok segítségével - ld. pl Les éditions des Chambres de Commerce et d'Industrie de Bretagne (2010--2011)) igyekeznek a családi cégek átörökítését segíteni.

12 E vizsgálatba nem kerültek be az FBN-H tagjai, tekintve, hogy a szövetség a felelös átörökítés kapcsán olyan szakmai támogatást ad tagjainak, aminek a hatására időben elkezdenek foglalkozni a felelős átörökítés folyamatával.

13 Nem véletlen, hogy hangsúlyt kap a „hazai” jelző. Ugyanis az erőszakos és a tulajdonosokat megbélyegző államosítás szocialista történelmi előzményeinek lenyomatai - megítélésem szerint - bár látensen és tudat alatt munkálva, de eléggé hatnak még ahhoz, hogy bármilyen módon és okon a család engedje, hogy bárki, pl. egy tanácsadó, a cég „,belsejébe” (viszonyaiba, tökehelyzetébe stb.) belelásson, „beleszóljon”. Noha, ez fontos érdeke lenne, az adott cégnek; ,klasszikusan” épp ilyen az átörökítési folyamat, amely talán a legbizalmasabb és legbelsőbb helyzetek egyike. Így az esetlegesen felvetődő átörökítési nehézségek bemutatása (akár még a tények és ismeretek puszta „tálalása”), s még annál fokozottabban, magát a folyamatot támogató segítségnek (legyen az képzési vagy tanácsadói) is erre tekintettel bizonyos, speciális vonásokkal kell bírnia.

14 A lehetséges családi cégek és interjúalanyainak „megtalálásába” bevontuk a BKIK TANOSZT szervezte gyakorlatokon tanácsadói szakirányos, levelező, mester, illetve posztgraduális változás- és válságmenedzser képzésben részt vevő hallgatóink közül, elsősorban az ilyen cégekben dolgozó és/vagy kapcsolati tőkéjükön keresztül segíteni szándékozó hallgatókat. Tekintve, hogy a családi cégek nagyon zárkózottak, nehezen megközelíthetőek, különösképp ,intim” kérdésekben, erre mindenképp szükségünk volt. Így lett kissé vegyes az interjúkban részt vett cégek köre, vagyis 12 gép- és autóipari beszállító cég, 8 hagyományos, nagy részben kézi technológiákra épülö (manufaktúra jellegü) cég, 6 mezőgazdasági és/vagy élelmiszeripari cég, 2 kereskedelmi tevékenységet folytató s 7 tudásigényes szolgáltatásokkal foglalkozó vállalkozás.

\section{Felhasznált irodalom}

Aycan, Z. (2006): Paternalism: Towards conceptual refinement and operationalization. in: Yang, K. S. - Hwang, K. K. - Kim, U. (eds.) (2006): Scientific advances in indigenous psychologies: Empirical, philosophical, and cultural contributions. London: Springer, p. 445466.

Aycan, Z. (2015): Paternalistic Leadership. International Management, vol.6. DOI: 10.1002/9781118785317

Carlock, R. S. - Ward, J. L. (2006): A családi vállalkozás stratégiai tervezése. Budapest: Helikon Kiadó

Csákné Filep Judit (2012): Családi vállalkozások - fókuszban az utódlás. (http://phd.lib.uni-corvinus.hu/660/1/ csakne filep judit dhu.pdf

Cheng, B. $\bar{S}$. $-\overline{C h o u,} \bar{L}$. F. - Farh, J. L. (2000): A triad model of paternalistic leadership: The constructs and measurement. Indigenous psychological research in Chinese Societies, 14, p. 3-64.

Danes, S. M. et al. (2008): The Effects of Ethnicity, Families and Culture on Entrepreneurial Experience: an Extension of Sustainable Family Business Theory.

Journal of Developmental Entrepreneurship, Vol. 13, No. 3, p. 229-268.

European Commission (2009): Final report of the expert group. Overview of family business relevant issues: research, networks, policy measures and existing studies. (http://ec.europa.eu/enterprise/policies/sme/ promoting-entrepreneurship/family-business/family business_expert_group_report_en.pdf)

Garai Katalin (2009): A világ 15 legrégebbi családi vállalkozása - A tradíció őrzése és fejlődni tudás a titok. Ügyvezető-, Menedzsment- és HR-portál http://www. ugyvezeto.hu/cikk/60158/a-vilag-15-legregebbi-csaladi-vallalkozasa-a-tradicio-orzese-es-fejlodni-tudas-a-titok?area $=166$

Hamvas Béla (2008): Mirázs (Patmosz II.). Budapest: Medio Kiadó

Heidrich, B. - Németh, K. - Chandler, N. (2016): Running in the Family - Paternalism and Familiness in the Development of Family Businesses. Vezetéstudomány, 11. sz., p. 70-82.

Huybrechts, J. - Voordeckers, W. - Lybaert, N. - Vandemaele, S. (2011): The Distinctiveness of Family Firm Intangibles: a Review and Suggestions for Future. Research Journal of Management \& Organization, Vol. 17, No. 2, p. 268-287.

Leach, P. (2007): Family businesses the essentials. London: Profile Books

HVG (2016): http://hvg.hu/kkv/20160913_A_csaladi_cegek_ketharmada_elverzik_a_generaciovaltasban

Les éditions des Chambres de Commerce et d'Industrie de Bretagne (2010 -2011): Transmettre son entreprise. http://www.bretagne.cci.fr/files/crci bretagne/publications/Transmettre-son-entreprise-2010-2011.pdf

Mellerio, O. (2011): Transmettre une entreprise familiale: Des solutions concrètes pour réussir la transmission. Groupe Eyrolles ISBN 978 - 2 - 212- 54845 - 7 
Noszkay Erzsébet (1997): Miért éppen az ezredfordulóra? - avagy hazai vállalkozások a férfikor küszöbén. in: Elméleti és gyakorlati kihívások az ezredforduló gazdaságában. Konferencia. Lillafüred: Miskolci Egyetem

Noszkay Erzsébet (2011): „Nincs királyi út!....” KKV-kihívások és lehetséges válaszok a mélyülő válság idején. in: AGTEDU tudományos konferencia kiadványa (lektorált, p. 22 - 28.)

Noszkay Erzsébet (2013): „Who will (or should) inherit the earth?" The new challenge of Hungarian change and crisis management: issues of responsible succession of family businesses Proceedings of the "Scientific Management" and Management Science Today International Scientific Conference, p. 348-358. ISBN 978963-306-176-3

Noszkay Erzsébet (2015): A felelős családi vállalkozás átörökítésének dilemmái és hazai problémái. „Mérleg és Kihívások" IX. Nemzetközi Tudományos Konferencia "Balance and Challenges" 9th International Scientific Conference, Miskolc-Lillafüred ISBN 978-963-358-098-1
Poza, E. J. - Daugherty, M. S. (2014): Family Business. Mason, $\mathrm{OH}$ : South-Western Cengage Learning

Pellegrini, E. K. - Scandura, T. A. (2008): Paternalistic leadership: A review and agenda for future research. Journal of Management, 34 (3), p. 566-593.

Rivers, W. (2015): Family Business Leadership Styles. The Family Business Institute, Inc. Available at: http:/www.familybusinessunited.com/family-business/management/family-business-leadership-styles/

Sheer, V. C. (2010): Transformational and paternalistic leaderships in Chinese organizations: Construct, predictive, and ecological validities compared in a Hong Kong sample. Intercultural Communication Studies, 19.1, p. 121-140. ISSN (print) 10577769 http://web.uri. edu/iaics/files/09VivianSheer.pdf

Sten, J. (2007): What is a business family? Electronic Journal of Family Business Studies, EJFBS Issue 2, Volume 1., p. 168-185.

\section{E SZÁMUNK SZERZŐI}

Prof. Dr. Szerb László, egyetemi tanár, Pécsi Tudományegyetem; Dr. Kocziszky György, egyetemi tanár, Miskolci Egyetem; Veresné Dr. Somosi Mariann, egyetemi tanár, dékán, Miskolci Egyetem; Dr. Balaton Károly, egyetemi tanár, Miskolci Egyetem; Dr. Borsi Balázs, egyetemi docens, Eszterházy Károly Egyetem; Dr. Reszegi László, címzetes egyetemi tanár, Budapesti Corvinus Egyetem; Dr. Juhász Péter, egyetemi docens, Budapesti Corvinus Egyetem; Dr. Tokár-Szadai Ágnes PhD., egyetemi docens, Miskolci Egyetem; Árváné Dr. Ványi Georgina, coach, egyetemi adjunktus, Debreceni Egyetem; Team Academy, Debrecen; Katonáné Dr. Kovács Judit, coach, Team Academy, Debrecen; Dr. Gál Tímea, coach, Team Academy, Debrecen; Dr. Hideg Éva, egyetemi docens, Budapesti Corvinus Egyetem; Dr. Gáspár Judit, egyetemi adjunktus, Budapesti Corvinus Egyetem; Demus Tamás, müszaki menedzser, Knorr Bremse Rail Systems, Budapest; Sugár Mihály, vezető tanácsadó, Bellresearch Kutatási és Tanácsadó Kft.; Tyukodi Gergely, PhD-hallgató, Budapesti Corvinus Egyetem; Dr. Noszkay Erzsébet professor emerita, Budapesti Metropolitan Egyetem; Dr. Agárdi Irma, egyetemi docens, Budapesti Corvinus Egyetem 